\title{
A monoclonal antibody that detects HLA-D region antigen in routinely fixed, wax embedded sections of normal and neoplastic lymphoid tissues
}

\author{
AA EPENETOS,${ }^{*} \dagger$ LG BOBROW,${ }^{*} \ddagger$ TE ADAMS,${ }^{*} \S$ CM COLLINS, $\ddagger$ PG ISAACSON, $\ddagger$ WF \\ BODMER*
}

From the *Imperial Cancer Research Fund, Lincoln's Inn Fields, London, the $\nmid$ Royal Postgraduate Medical School, Hammersmith Hospital, London, the $\ddagger$ Department of Histopathology, University College, London and the Middlesex Hospital Medical School, London, and the §Cold Spring Harbor Laboratories, New York, USA

SUMMARY We describe the use of a monoclonal antibody (TAL-IB5) to HLA-D region $\alpha$-chains that reacts well with HLA-D positive cells in normal and neoplastic lymphoid tissues fixed in routine fixatives and embedded in paraffin wax in the conventional fashion. This antibody should prove to be useful in routine histological investigations of lymphoid and possibly other neoplasms as well as other non-neoplastic conditions where the immune system plays an important part.

The HLA region contains several closely linked loci controlling cell surface determinants, genes for immune responsiveness, and certain components of the complement system.'

HLA-ABC antigens are found in varying amounts on almost all nucleated cells. ${ }^{2}$ On the other hand, HLA-D region antigens show a much more restricted distribution and are expressed mainly by cells directly involved in immune response such as B lymphocytes, macrophages, dendritic reticulum cells, ${ }^{3}$ activated T cells, ${ }^{4}$ as well as Langerhans' cells ${ }^{5}$ and some endothelial cells. ${ }^{6-8}$

A clearer understanding of the importance and relevance of the HLA-D antigens will ultimately come from their molecular characterisation, but already serological studies using both polyclonal and more recently monoclonal antibodies to HLA-D products $^{910}$ on cryostat sections of fresh frozen tissues have become valuable adjuncts to the classification of lymphoproliferative and other disorders. Unfortunately, most of the antibodies described so far do not react with routinely fixed, wax embedded sections. This has been a major limitation in their use, especially for retrospective studies on large numbers of tissues. The quality of cryostat sections is inferior to that of formalin fixed, wax embedded sections and so antibodies which react with the latter are needed. Here we describe

Accepted for publication 22 August 1984 the use of a monoclonal TAL-IB5 to separated HLA-D region $\alpha$-chains ${ }^{11}$ which can be used in immunocytochemical analysis of routinely fixed, paraffin wax embedded sections.

\section{Material and methods}

MONOCLONAL ANTIBODIES

$T A L-I B 5$

This IgGl monoclonal antibody was produced by conventional procedures using a spleen from a $\mathrm{Balb} / \mathrm{C}$ mouse that had been extensively immunised with the purified $33 \mathrm{~K} \alpha$-chain subunit of HLA-D products. ${ }^{11}$ Specificity of the antibody for the $\alpha$-chain subunit was initially shown using a solid phase radioimmunoassay on purified HLA-D $\alpha$-chains and subsequently by immunoprecipitation analysis and reactivity on a variety of cell lines and tissues.

\section{Positive control PD7/26}

This antibody was kindly supplied by Dr D Y Mason of the John Radcliffe Hospital, Oxford. It has been positive in over $90 \%$ of human lymphomas studied and negative in $100 \%$ of tumours from other categories. ${ }^{12}$ The antibody probably identifies the T200 leucocyte common antigen.

TISSUE FIXATION

The tissues used in this study were fixed in acid for- 
Table 1 Normal lymphoid tissues

\begin{tabular}{lll}
\hline Tissue & & TAL-IB5 staining \\
\hline Normal tonsil and normal lymph node & B cells in germinal centre & + \\
& B cells in mantle zone & + \\
& Interdigitating cells & + \\
Normal thymus & Macrophages & + \\
& Population of medullary cells & $($ Fig. 1) \\
& Interdigitating cells & + \\
\hline
\end{tabular}

malin ( $2 \%$ acetic acid in $4 \%$ formaldehyde), Bouin's fixative, or unbuffered formol-saline.

\section{IMMUNOPEROXIDASE REACTION}

Tissue sections were dewaxed and taken to industrial methylated spirits. Endogenous peroxidase was inhibited with freshly prepared $0.5 \%$ hydrogen peroxide in methanol for 10 to $15 \mathrm{~min}$ at room temperature. Trypsin digestion ${ }^{13}$ was used in the initial stages of the study, but this step was subsequently omitted. TAL-IB5 supernatant was applied to the sections for $60 \mathrm{~min}$ at room temperature. This was followed by peroxidase conjugated rabbit antimouse immunoglobulin. The peroxidase reaction was developed using diaminobenzidine, imidazole (Sigma I-0125), and hydrogen peroxide. Sections were then counterstained with haematoxylin.

Sections were tested in parallel with PD7/26.

\section{Results}

Reliable immunoperoxidase staining with TAL-IB5 was obtained on tissues fixed in acid formalin for up to $24 \mathrm{~h}$ or Bouin's fixative or other mercury containing fixatives. Tissues fixed in buffered formol-saline gave poor results and tissues fixed in unbuffered formol-saline gave variable results. Pretreatment with trypsin did not recover immunoperoxidase demonstration of the antigen in overfixed tissues or tissues fixed in buffered formol-saline.

Tables 1 and 2 summarise the results of immunoperoxidase staining of normal lymphoid tissues and of 48 lymphomas with the antibody TALIB5.

NORMAL TISSUES

The antibody stained B cells in the mantle zone of

\section{Table 2 Diagnosis of lymphomas}

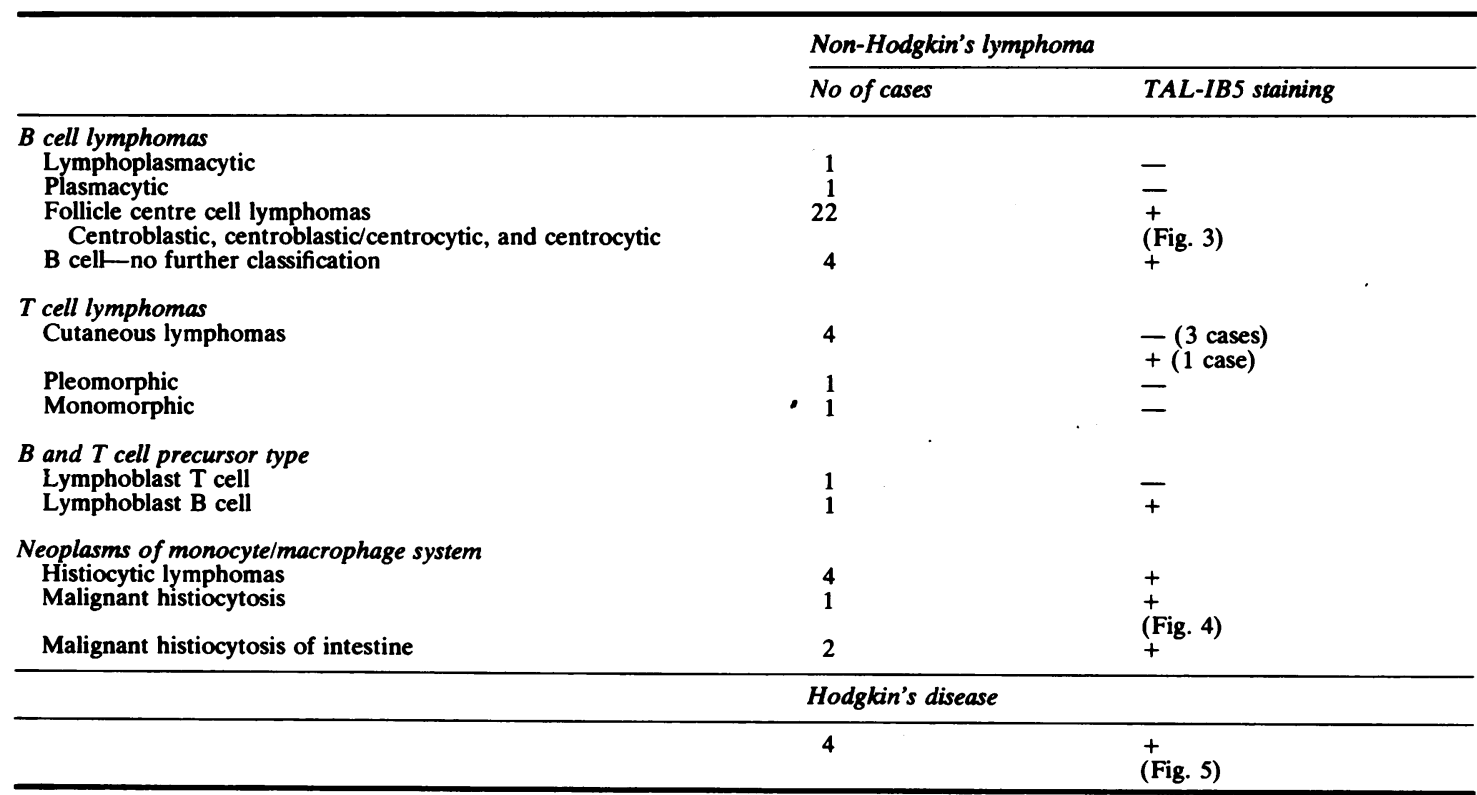




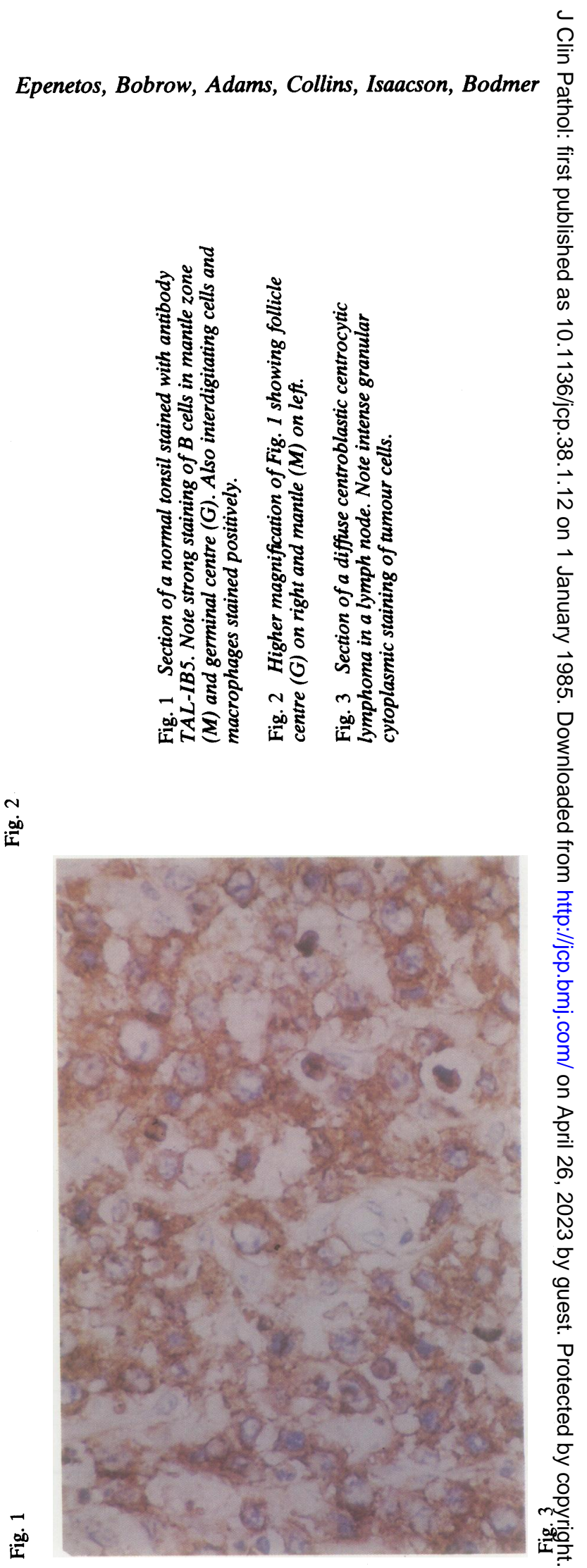



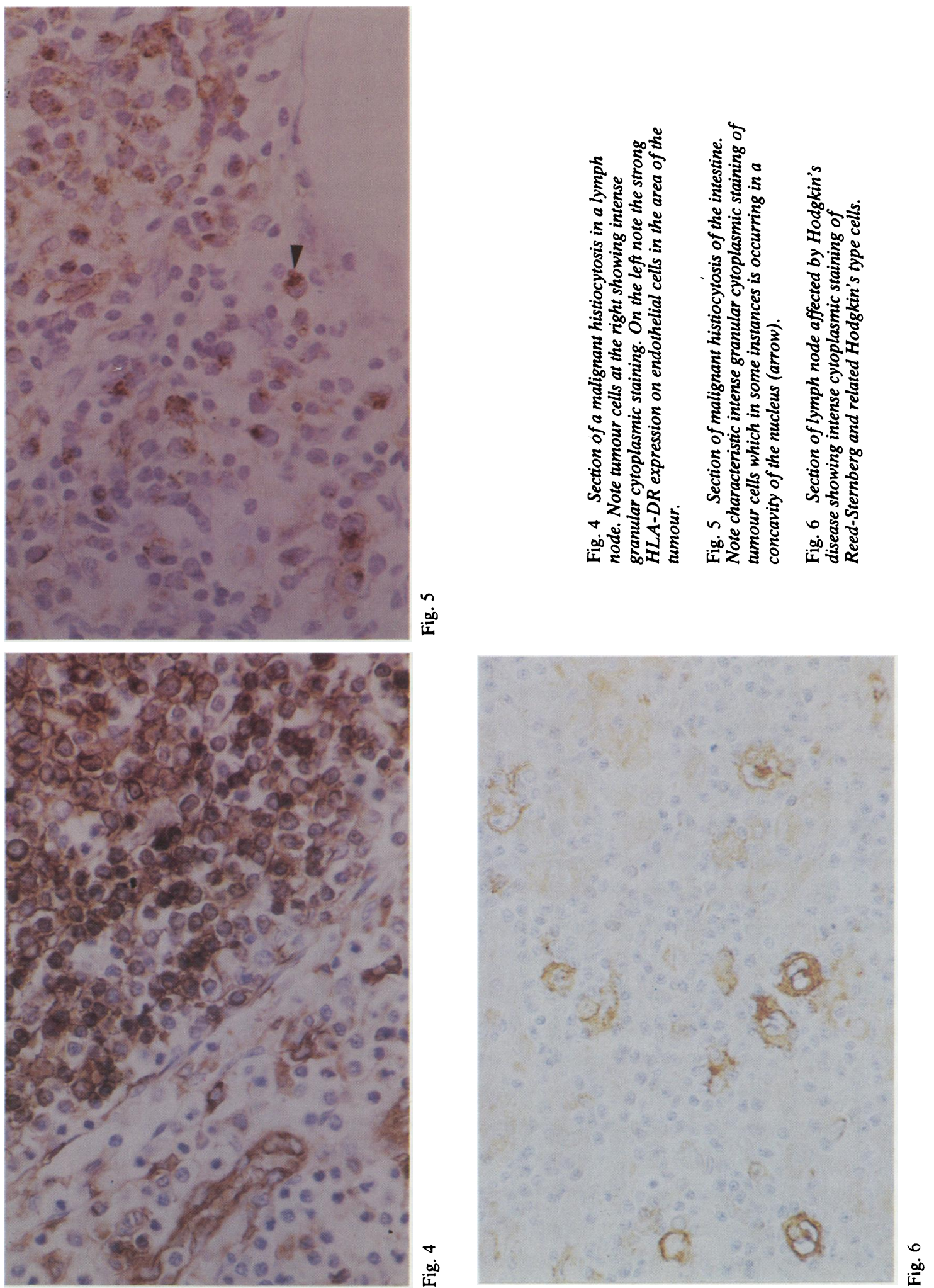
lymph node and tonsils, with diffuse cytoplasmic staining. The antibody also stained B cells in the follicle centre of lymph node and tonsil. The staining in these cells appeared to be on or adjacent to the cell membranes. Interdigitating reticulum cells in these organs also showed positive diffuse cytoplasmic staining.

\section{NEOPLASTIC TISSUES}

Over a period of about two years, starting in early 1982, we used TAL-1B5 in conjunction with PD7/ 26 to help in the diagnosis and typing of 48 lymphomas seen in the histopathology department at University College. The lymphomas were typed morphologically according to a modified Kiel classification. ${ }^{14}$

Of these, 48 cases were $B$ cell lymphomas, two of which gave negative reactions with TAL-IB5. One of these was lymphoplasmacytic and the other was plasmacytic in type. The remaining 26 all gave strong positive reactions with TAL-IB5: 22 of these were follicle centre cell lymphomas and the remaining four could not be further categorised morphologically. All 26 cases showed diffuse cytoplasmic staining and strong membrane staining of the tumour cells.

Seven of the 48 cases were $T$ cell lymphomas. Five were cutaneous, one was pleomorphic, and one was monomorphic. Six of the seven did not stain with TAL-IB5. One of the cutaneous lymphomas showed positive staining with TAL-IB5.

Two of the 48 cases fell into B and T cell precursor type. One was a lymphoblastic $\mathrm{T}$ cell lymphoma, which did not stain with TAL-IB5, and one was a lymphoblastic B cell lymphoma, which showed strong positive granular cytoplasmic staining of the tumour cells.

Seven of 48 cases were lymphomas of the monocyte/macrophage system, of which four were histiocytic lymphomas, one was a case of malignant histiocytosis, and two were cases of malignant histiocytosis of the intestine. All seven cases showed intense positive staining of some or many tumour cells with TAL-IB5. The staining was mostly of the diffuse granular cytoplasmic type often located particularly densely in a part of the cytoplasm indented into a concavity of the nucleus (Fig. 5). These seven cases were also checked for $\alpha_{1}$-antitrypsin expression using a polyclonal antibody (Dako Lot 081A Exp 0887) and for non-specific esterase activity. Five of the seven cases were positive for at least one of the markers. The remaining two cases were diagnosed as histiocytic lymphomas on morphological grounds alone.

Four of the 48 cases were Hodgkin's disease of the nodular sclerosing type. All four cases showed strong granular cytoplasmic staining of ReedSternberg and Hodgkin's cells with the TAL-IB5 antibody.

All of the 48 cases studied showed positive staining of lymphoma cells using the PD7/26 antibody.

\section{Discussion}

Our work shows how a monoclonal antibody that can detect HLA-DR positive cells in fixed paraffin embedded tissues is an invaluable tool in the routine diagnosis and classification of malignant lymphomas when used in conjunction with PD7/26. TAL-IB5 defines B cell tumours in general, giving particularly characteristic staining in the follicular and histiocytic lymphomas. Occasional $\mathrm{T}$ cell tumours which arise from a clone of activated $T$ cells will be positive with TAL-IB5. Several such tumours have recently been reported from Japan ${ }^{15}$ and from the UK (Habeshaw, personal communication). Provided one is aware of this possibility it should not detract from the usefulness of this antibody in the context stated above.

Whether or not the expression of HLA-D is an important factor in the behaviour of neoplastic cells and their interactions with normal cells can now be studied on a retrospective as well as a prospective basis and definitive data on prognosis may be obtained. The variation in HLA-D expression on endothelial cells in both normal and neoplastic tissue is another field of study that can now be addressed more readily. The increased expression of HLA-D in tissues involved in autoimmune disease ${ }^{16}$ is yet another problem, and it should be possible to study this using an antibody which reacts readily on fixed paraffin wax embedded tissues.

In conclusion, TAL-IB5 is a monoclonal antibody against the HLA-D region antigen which reacts well on paraffin embedded tissue which has been fixed in unbuffered formalins such as acid formalin, Bouin's, or mercurial fixatives. Tissue fixed in neutral buffered formalin gave poor results. It is therefore an $I$ antibody which may be used in most hospital pathology laboratories and is a valuable diagnostic $N$ reagent, being reactive with normal and neoplastic lymphoid tissue. It also makes the study of HLA-D expression on tissue sections in both neoplastic and non-neoplastic disease a more widespread possibility than it has been until now.

We thank $J$ Habershaw and $M$ Greaves of the Imperial Cancer Research Fund, London, and DY $\stackrel{\vec{D}}{\vec{D}}$ Mason of the John Radcliffe Hospital, Oxford, for $\stackrel{?}{\mathbb{Q}}$ their help; K Miller and P Walpole of University $\stackrel{\square}{\square}$ College Hospital and Cynthia Dixon and Helga Durbin of the Imperial Cancer Research Fund, 
London, for their invaluable technical assistance; and Margaret Hollis for typing the manuscript.

\section{References}

' Bodmer WF, Bodmer JG. Evolution and function of the HLA system. Br Med Bull 1978;34:309.

${ }^{2}$ Brodsky FM, Parham P, Barnstable CJ, et al. Monoclonal antibodies for analysis of the HLA system. Immunological Reviews 1979;47:3.

${ }^{3}$ Snary DD, Barnstable CJ, Bodmer WF, et al. Cellular distribution, purification and molecular nature of human Ia antigens. Scand J Immunol 1977;6:439.

4 Albrechtsen D, Solheim BG, Thorsby E. The presence of Ia-like determinants on a subpopulation of human $\mathrm{T}$ lymphocytes. Immunogenetics 1977;5:149.

${ }^{5}$ Klareskog L, Tjernlund VM, Forsum V, et al.Epidermal cells express Ia antigens. Nature 1977;268:248.

${ }^{\circ}$ Hirschberg H, Evensen SA, Henricksen TA. The mixed lymphocyte-endothelium culture interaction. Transplantation 1975; 19:495.

' Fuggle SV, Errasti P, Daar AS. Localisation of major histocompatibility complex (HLA-ABC and DR) antigens in 46 kidneys. Transplantation 1983;35:375.

${ }^{8}$ Bodmer G, Bodmer WF. Monoclonal antibodies to HLA determinants. Br Med Bull (in press).

${ }^{9}$ Bhan AK, Reinherz EL, Poppera S, et al. Location of T-cells and major histocompatibility complex antigens in the human thymus. J Exp Med 1980;152:771-81.
${ }^{10}$ Kohler G, Milstein C. Derivation of specific antibody producing tissue culture and tumour lines by cell fusion. Eur J Immunol 1976;6:551.

" Adams TE, Bodmer G, Bodmer WF. Production and characterisation of monoclonal antibodies recognising the $\alpha$ chain subunits of human Ia alloantigens. Immunology 1983;50:613.

12 Warnke RA, Gatter KC, Falini B, et al. Diagnosis of human lymphoma with monoclonal antileucocyte antibodies. $N$ Engl J Med 1983;309:1275-81.

${ }^{13}$ Mepham BL, Frater W, Mitchell BS. The use of proteolytic enzymes to improve immunoglobulin staining by the PAP technique. Histochem J 1979; 11:345-57.

14 Wright DH, Isaacson PG. Biopsy pathology series. London: Chapman and Hall, 1983.

is Takatsuki K, Uchiyama T, Veshima Y, et al. Adult T-cell leukaemia: further clinical observation and cytogenetics and functional studies of leukaemia cells. Japanese Journal of Clinical Oncology 1979; (suppl): 317.

${ }^{16}$ Hanafusa T, Chlovato L, Doniach D, et al. Aberrant expression of HLA-DR antigen on thyrocytes in Graves' disease; Relevance for autoimmunity. Lancet 1983;ii:1111-5.

Requests for reprints to: Dr LG Bobrow, Department of Histopathology, Faculty of Clinical Sciences, University College Hospital, University Street, London WC1 6JJ, England. 